\title{
EXECUÇÃO ANTECIPADA DA PENA: MUTAÇÃO OU VIOLAÇÃO DA CONSTITUIÇÃO?
}

Gabriel Heller*

SUMÁRIO: Introdução; 2 Do direito fundamental à não execução antecipada da pena; 2.1 Da distinta autorização constitucional para a prisão cautelar e a prisão-sanção; 2.2 Dos conceitos jurídicos determinados constantes do Art. $5^{\circ}$, LVII, da Constituição Federal; 2.3 Da exigência do trânsito em julgado da sentença condenatória para que o indivíduo seja punido; 3 Da inconstitucionalidade da execução antecipada da pena; 3.1 Do direito fundamental à não execução antecipada da pena como regra jurídica; 3.2 Da violação do núcleo essencial do direito fundamental em caso de execução penal antecipada; 4 Conclusão; Referências.

RESUMO: O presente artigo analisa a possibilidade, na ordem constitucional vigente, da execução de condenação penal não transitada em julgado. Na primeira parte do trabalho, visando demonstrar a existência, no ordenamento jurídico brasileiro, de um direito à não execução antecipada da pena, distinguem-se os conceitos de prisão cautelar e prisão-sanção, bem como os dispositivos constitucionais que as autorizam. Igualmente se apresenta a diminuta margem interpretativa deixada pelo constituinte aos juízes no que tange ao cumprimento de sentença penal condenatória, exigindo-se o trânsito em julgado dessa sentença. Na segunda parte do artigo, advoga-se a inconstitucionalidade da execução antecipada da pena, a partir da diferenciação entre regras e princípios jurídicos e da evidenciação de que o inciso LVII do art. $5^{\circ}$ da Constituição Federal constitui regra jurídica, não passível, portanto, de ponderação.

PALAVRAS-CHAVE: Cumprimento da pena; Trânsito em julgado; Direitos fundamentais; Mutação constitucional; Supremo Tribunal Federal.

\section{THE ANTICIPATED EXECUTION OF SANCTIONS: CHANGES OR VIOLATION OF THE CONSTITUTION?}

ABSTRACT: The Current paper analyzes the possibility within the present constitution of implementing penal condemnation prior to transit in rem judicatam. The first section shows the existence within Brazilian law of the right to anticipated non-execution of sanctions. There is a distinction between the concepts of caution

*Auditor de Controle Externo do Tribunal de Contas do Distrito Federal. Mestre em Direito (UNICEUB), Brasil. E-mail: hellergabriel@hotmail.com 
prison and sanction prison and the constitutional items that authorize them. The slight interpretation margin, conceived by the constituent for judges with regard to the execution of the condemnatory sentence, requires transit in rem judicatam. The second section insists on the non-constitutionality of anticipated execution of sanctions through the differentiation between juridical rules and principles. The above shows that item LVII of Art. 5 of the Brazilian Constitution is a juridical rule and does not require balancing.

KEY WORDS: Execution sanctions; Transit in rem judicatam; Fundamental rights; Constitutional changes; Supreme Federal Courts.

\section{EJECUCIÓN ANTICIPADA DE LA PENA: ¿MUTACIÓN O VIOLACIÓN DE LA CONSTITUCIÓN?}

RESUMEN: En el presente artículo se analiza la posibilidad, en el orden constitucional vigente, de la ejecución de condenación penal no transitada en juzgado. En la primera parte del estudio, visando demonstrar la existencia, en el ordenamiento jurídico brasileño, de un derecho a la no ejecución anticipada de la pena, se distinguen los conceptos de prisión cautelar y prisión-sanción, así como los dispositivos constitucionales que las autorizan. Igualmente se presenta la diminuta margen interpretativa dejada por el constituyente a los jueces con respeto al cumplimiento de sentencia penal condenatoria, exigiéndose el tránsito en juzgado de esa sentencia. En la segunda parte del artículo, se defiende la inconstitucionalidad de la ejecución anticipada de la pena, a partir de la diferenciación entre reglas y principios jurídicos y de la evidencia de que el inciso LVII do art. $5^{\circ}$ de la Constitución Federal constituye regla jurídica, no pasible, por lo tanto, de ponderación.

PALABRAS CLAVE: Cumplimiento de la pena; Tránsito en juzgado; Derechos fundamentales; Mutación constitucional; Supremo Tribunal Federal.

\section{INTRODUÇÃO}

Apanágio das democracias constitucionais modernas, o princípio da presunção de inocência foi positivado no art. 9 da paradigmática Declaração dos Direitos do Homem e do Cidadão de $1789^{02}$. Dali em diante, boa parte das declarações internacionais de direitos e das constituições nacionais reproduziu normas de teor se-

\footnotetext{
$\overline{02}$ "Art. 9. Tout homme étant présumé innocent jusqu'à ce qu'il ait été déclaré coupable, s'il est jugé indispensable de l'arrêter, toute rigueur qui ne serait pas nécessaire pour s'assurer de sa personne doit être sévèrement réprimée par la loi". Disponível em: https://www.legifrance.gouv.fr/Droit-francais/Constitution/Declaration-des-Droits-de-l-Homme-et-du-Citoyen-de-1789. Acesso em 22 de novembro de 2017.
} 
melhante, ora mais abrangentes, ora menos, merecendo destaque a Declaração Universal dos Direitos Humanos, aprovada na Organização das Nações Unidas (ONU) em $1948^{03}$.

No Brasil, até o advento da Constituição Federal de 1988 (CF/88), a ideia de presunção de inocência existia apenas como corolário da cláusula do devido processo legal ${ }^{04}$. A Constituição Cidadã mudou tal cenário, prevendo, em seu Título II, "Dos Direitos e Garantias Fundamentais", que "ninguém será considerado culpado até o trânsito em julgado de sentença penal condenatória" (art. $\left.5^{\circ}, \mathrm{LVII}\right)$.

Em 1991, ao julgar o HC n 68.726, o Supremo Tribunal Federal (STF) firmou o entendimento de que tal dispositivo constitucional não vedaria a ordem de prisão de réu condenado em segunda instância. O voto condutor desse julgado fundamentou-se, basicamente, no fato de o art. 669 do Código de Processo Penal (CPP), assim como o $\S 2^{\circ}$ do art. 27 da lei 8.038/1990, não atribuir aos recursos extraordinário (RE) e especial (REsp) efeito suspensivo ${ }^{05}$.

Tal orientação jurisprudencial perdurou até o ano de 2009, quando, ao julgar o $\mathrm{HC} \mathrm{n}^{\circ} 84.078$, o STF alterou sua jurisprudência e passou a proibir a execução antecipada (ou provisória) da pena. Naquele momento, entendeu a Suprema Corte que, ausentes os requisitos de prisão cautelar, o recolhimento do indivíduo ao cárcere só poderia ocorrer após o trânsito em julgado da sentença condenatória.

Reconhecendo o acerto da decisão do Poder Judiciário, o Congresso Nacional, por meio da lei $n^{0} 12.403 / 2011$, deu nova redação ao art. 283 do CPP, passando a estabelecer, em consonância com o inciso LVII do art. $5^{\circ} \mathrm{da} C F$, que

Ninguém poderá ser preso senão em flagrante delito ou por ordem escrita e fundamentada da autoridade judiciária competente, em decorrência de sentença condenatória transitada em julgado ou, no curso da investigação ou do processo, em virtude de prisão temporária ou prisão preventiva.

Contudo, em fevereiro de 2016, em julgamento do $\mathrm{HC} \mathrm{n}^{0} 126.292^{06}$, por

\footnotetext{
${ }^{03}$ Art. 11.1: "Todo ser humano acusado de um ato delituoso tem o direito de ser presumido inocente até que a sua culpabilidade tenha sido provada de acordo com a lei, em julgamento público no qual the tenham sido asseguradas todas as garantias necessárias à sua defesa". Disponível em: http://www.onu.org.br/img/2014/09/ DUDH.pdf. Acesso em 22 de novembro de 2017.

${ }^{04}$ LIMA, Renato Brasileiro de. Manual de processo penal: volume único. 5. ed. rev., ampl. e atual. Salvador: Ed. JusPodivm, 2017, p. 43.

${ }^{05}$ STF. HC n ${ }^{\circ}$ 68726/DF. Tribunal Pleno. Relator Ministro Néri da Silveira. Publicado no DJ em 20/11/1992.

${ }^{06}$ STF. HC no 126.292/SP. Tribunal Pleno. Relator Ministro Teori Zavascki. Publicado no DJe em 17/05/2016.
} 
maioria de sete votos a quatro, o STF retornou ao entendimento prevalecente até 2009, dando contornos mais restritos à máxima da presunção de inocência e viabilizando a execução provisória da pena. Os argumentos dos votos vencedores podem ser assim resumidos: a) exige-se um equilíbrio entre o princípio da presunção de inocência e a efetividade da jurisdição penal, que tem um dever de proteção perante a sociedade; b) o exame de fatos e provas é encerrado nas instâncias judiciais ordinárias, sendo restrita a matéria a ser tratada em RE e REsp; c) após a condenação em segundo grau do acusado, é válido relativizar e até mesmo inverter-se a presunção de sua inocência; d) o art. 283, CPP, alterado pela lei ${ }^{0}$ 12.403/2011, não revogou todas as formas de encarceramento que não a prisão em flagrante, a temporária, a preventiva e a decorrente de sentença penal condenatória transitada em julgado; e) seguindo a regra do lex posterior derogat legi priori, prevaleceria a regra do CPC que atribui apenas o efeito devolutivo aos recursos ao STJ e ao STF, aplicável subsidiariamente ao processo penal (artigos 995 e 1.029, § $5^{\circ}$ ); f) o direito comparado demonstra ser compatível com o princípio da presunção de inocência a execução da pena após julgamento em segunda instância; g) a jurisprudência superada vinha ensejando a indevida e sucessiva interposição de recursos meramente protelatórios; h) o réu poderia se valer de medidas cautelares para atribuir efeito suspensivo a seu recurso ou de habeas corpus para impedir a execução antecipada da pena ${ }^{07}$.

Essa orientação foi confirmada no julgamento da medida cautelar das Ações Declaratórias de Constitucionalidade (ADC) no 43 e 44 e no ARE n ${ }^{\circ} 964.246$ (RE com repercussão geral reconhecida), no fim de 2016.

O presente artigo pretende, assim, analisar criticamente a legislação, a doutrina constitucional e penal e os fundamentos das decisões da Suprema Corte no que respeitam a esse tema, visando demonstrar a inconstitucionalidade da execução antecipada da pena.

Busca-se, na primeira parte, evidenciar que o inciso LVII do art. $5^{\circ}$ da CF constitui, mais do que uma presunção de inocência, um direito fundamental à não execução antecipada da pena, diferenciando os regimes de prisão cautelar e de prisão penal (prisão-sanção) e destrinchando os conceitos jurídicos que enformam o dispositivo constitucional, para argumentar que o trânsito em julgado que autoriza a execução da pena só se opera após o julgamento de eventuais recursos extraordinário ou especial interpostos.

${ }^{07}$ Cf. LIMA, Renato Brasileiro de. Manual de processo penal: volume único. 5. ed. rev., ampl. e atual. Salvador: JusPodivm, 2017, p. 47-48. 
Na segunda e última parte deste trabalho, adotando-se a consagrada classificação das normas em normas-regras e normas-princípios, defende-se que o direito fundamental veiculado pela norma constitucional aludida é típica regra jurídica, não sujeita, portanto, a aplicação por meio de ponderação. Por conseguinte, ao final, advoga-se a impossibilidade de se fazer cumprir sanções penais antecipada e provisoriamente.

\section{DO DIREITO FUNDAMENTAL À NÃO EXECUÇÃO ANTECIPADA DA PENA}

Como princípio basilar para que se evite o cometimento de injustiças por parte do Estado, a presunção de inocência é reconhecida como direito fundamental por todas as verdadeiras democracias constitucionais. Entretanto, positivada e interpretada de formas diversas ao longo dos tempos e conforme o ordenamento, tal ideia está longe de corresponder a um único e estanque standard.

No Brasil de 1988, saído de um regime autoritário marcado pelo desrespeito aos direitos e garantias fundamentais, notadamente de caráter penal e processual penal, o constituinte conferiu contornos mais claros e rígidos a essa presunção. Assim, a dicção constitucional permite afirmar que existe um verdadeiro direito fundamental à não execução antecipada da pena. Para demonstrá-lo, cumpre diferenciar, a partir de uma perspectiva constitucional, os regimes de prisão cautelar e de prisão-sanção, para, a seguir, analisar os conceitos jurídicos determinados que compõem a regra do inciso LVII do art. $5^{\circ} \mathrm{e}, \mathrm{com}$ isso, evidenciar a necessidade do trânsito em julgado da sentença condenatória para que se possa executar a pena cominada ao indivíduo.

2.1 DA DISTINTA AUTORIZAÇÃO CONSTITUCIONAL PARA A PRISÃO CAUTELAR E A PRISÃO-SANÇÃO

Em qualquer ordenamento jurídico que tenha a liberdade como princípio fundamental, o encarceramento dos indivíduos, seja a que título for, é tido como $u l$ tima ratio do sistema. Parte-se sempre do pressuposto de que o ser humano é livre e assim deve continuar, sem descurar que a segregação de determinados membros da sociedade faz-se, eventualmente, necessária para resguardar bens jurídicos destes, em especial, sua vida e sua segurança. Tal segregação, operada pela prisão, pode se 
dar de maneira definitiva ou provisória, nas hipóteses e condições previstas em cada ordem normativa.

$\mathrm{Na}$ Constituição Federal de 1988, o art. $5^{\circ}$ traz, junto a direitos fundamentais de ordem geral, direitos fundamentais de índole processual penal, que o constituinte fixou de forma minudente com o intuito de defender a liberdade tão restringida no período autoritário que antecedeu a $\operatorname{Carta}^{08}$.

Entre esses direitos, incluem-se os previstos nos incisos LIV e LXI do referido artigo, que dispõem, respectivamente que "ninguém será privado da liberdade ou de seus bens sem o devido processo legal" e que "ninguém será preso senão em flagrante delito ou por ordem escrita e fundamentada de autoridade judiciária competente, salvo nos casos de transgressão militar ou crime propriamente militar, definidos em lei".

Tais dispositivos constituem as balizas para a imposição de prisões cautelares: a prisão que não em flagrante demanda ordem escrita e fundamentada de autoridade judiciária competente e, enquanto forma de privação da liberdade, deve respeitar o devido processo legal. Os casos e condições em que cabíveis a prisão cautelar foram deixados ao encargo do legislador ordinário, a quem incumbe delinear o procedimento a ser seguido, materializando o due process.

Como instrumentos que visam garantir a eficácia e utilidade do processo penal, as prisões processuais representam medidas indispensáveis à proteção de bens jurídicos pertencentes a toda a coletividade ${ }^{09}$. Em função de sua necessidade e da salvaguarda que objetiva, uma vez respeitados os limites conferidos pela Constituição, não há como se tratar a prisão cautelar como ilegítima ${ }^{10}$, embora se reconheça o risco de cometimento de injustiças que tal providência representa.

Por suas caraterísticas, a prisão cautelar tem como requisito o que a doutrina especializada denomina fumus commissi delicti, isto é, a probabilidade de ocorrência de um delito, configurada pela prova da existência do crime e por indícios suficientes de autoria, conforme o art. 312, CPP. O fundamento da prisão cautelar, por sua vez, é o periculum libertatis, o risco de frustração da função punitiva ou de

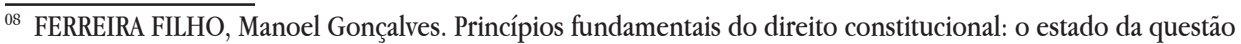
no início do século XXI, em face do direito comparado e, particularmente, do direito positivo brasileiro. 4. ed. São Paulo: Saraiva, 2015, p. 233.

${ }^{09}$ GRANDIS, Rodrigo de. Prisões processuais: uma releitura à luz do garantismo penal integral. In: CALABRICH, Bruno; FISCHER, Douglas; PELELLA, Eduardo. Garantismo penal integral: questões penais e processuais, criminalidade moderna e a aplicação do modelo garantista no Brasil. 2 ed. Salvador: JusPodivm, 2013, p. 401.

${ }^{10}$ Em sentido contrário, cf. LOPES JUNIOR, Aury. Direito processual penal. 14. ed. São Paulo: Saraiva, 2017, p. 586. 
graves prejuízos ao processo decorrente do estado de liberdade do acusado ${ }^{11}$.

Nessa senda, diante de situações concretas, o ordenamento brasileiro autoriza a adoção de providências urgentes e imperiosas para assegurar a apuração do delito, a eventual execução da sanção, a proteção da coletividade, ameaçada pelo risco de reiteração da conduta delituosa, ou o ressarcimento do dano causado pela conduta delituosa ${ }^{12}$.

Outro é o regime constitucional estipulado para a prisão-sanção, a prisão como pena - e não como cautela. Essa espécie de prisão decorre, por força do inciso LVII do art. $5^{\circ}$, de sentença condenatória transitada em julgado. Expressa, assim, a satisfação da pretensão punitiva estatal, caracterizando-se por sua definitividade ${ }^{13}$.

De modo a harmonizar o encarceramento de réu antes do trânsito em julgado com a norma referida, sem que estejam presentes os requisitos das prisões cautelares, criou-se a "prisão decorrente de sentença condenatória recorrível" como modalidade de prisão processual ${ }^{14}$. Ocorre, contudo, que tal espécie de encarceramento não mais se encontra prevista no ordenamento jurídico - nem poderia se encontrar.

Trazer, como fundamento da prisão, o fato de ter havido condenação recorrível significa tratar o acusado como culpado antes do trânsito em julgado, o que a Constituição veda diretamente. A única opção lícita para a prisão, nesse caso, é fazer acompanhar evidência em concreto do periculum libertatis - e, nessa hipótese, tratar-se-ia de uma prisão cautelar, e não de uma prisão "decorrente de sentença condenatória recorrível".

Veja-se que a Lei Fundamental não traz restrições claras e precisas à previsão de medidas cautelares penais pelo legislador, deixando-lhe margem relativamente ampla de atuação. Caso distinto se verifica quanto à execução da pena, em que a proteção constitucional se faz mais minudente, demandando que o tratamento como culpado - isto é, a aplicação de pena - dê-se apenas com o trânsito em julgado da sentença penal condenatória.

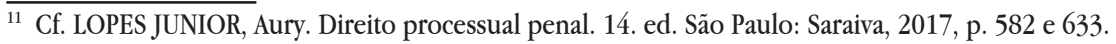

${ }^{12}$ LIMA, Renato Brasileiro de. Manual de processo penal: volume único. 5. ed. rev., ampl. e atual. Salvador: JusPodivm, 2017, p. 829.

${ }_{13}$ LIMA, Renato Brasileiro de. Manual de processo penal: volume único. 5. ed. rev., ampl. e atual. Salvador: JusPodivm, 2017, p. 863 e 875.

${ }^{14}$ Nesse sentido, GRANDIS, Rodrigo de. Prisões processuais: uma releitura à luz do garantismo penal integral. In: CALABRICH, Bruno; FISCHER, Douglas; PELELLA, Eduardo. Garantismo penal integral: questões penais e processuais, criminalidade moderna e a aplicação do modelo garantista no Brasil. 2. ed. Salvador: JusPodivm, 2013, p. 408.
} 
Assim dispondo, logrou o constituinte estabelecer justo equilíbrio entre o direito à liberdade e o princípio da presunção de inocência, de um lado, e o direito à segurança e o princípio da efetividade da jurisdição penal, de outro ${ }^{15}$.

Diante dessa realidade, cumpre notar o dever de interpretar os requisitos da prisão cautelar à luz do sistema constitucional como um todo, considerando tanto o direito fundamental à liberdade quanto a efetividade da jurisdição penal e $\mathrm{o}$ direito à segurança $\left(\right.$ art. $\left.6^{\circ}\right)$, sob pena de se ler $\mathrm{o}$ art. $5^{\circ}$ como superior às demais normas constitucionais. O que não se pode fazer é tratar prisão cautelar e prisão-sanção como se fossem uma só e mesma coisa, com fundamentos e condicionantes idênticos. Interpretação demasiado restritiva dos requisitos das cautelares constitui, frequentemente, verdadeira proteção insuficiente, também violatória da CF (artigos $6^{\circ}$ e $\left.144, \mathrm{CF}\right)^{16}$.

Nessa senda, registre-se a divergência em relação ao pensamento de estudiosos de viés mais garantista, no sentido de que a prisão preventiva para garantia da ordem pública ou da ordem econômica configuraria execução antecipada da pena ${ }^{17}$. A vagueza do conceito de garantia da ordem pública (ou da ordem econômica) enseja o máximo cuidado na utilização desse fundamento para aplicação da prisão cautelar, bem como a demonstração concreta do perigo que a liberdade do acusado gera, nada mais, nada menos. Ademais, o caráter cautelar da prisão provisória exige que esta dure o tempo necessário ao resguardo do bem jurídico que a justificou, não se confundindo com execução antecipada da pena, motivo pelo qual se admite sua revogação simplesmente sob o fundamento de excesso de prazo ${ }^{18}$.

Assim, resta claro que a prisão cautelar tem natureza de salvaguarda perante riscos concretamente demonstrados a bens jurídicos reputados dignos de proteção pelo legislador, ao passo que a prisão-sanção se presta, como indica o art. 59 do Código Penal, à reprovação (retribuição) e à prevenção (geral e especial) do crime ${ }^{19}$, aplicada não mais a um acusado, mas a um indivíduo considerado culpado.

${ }^{15}$ Em sentido aproximado, destacando a excepcionalidade da medida cautelar e sua qualidade instrumental, LIMA, Renato Brasileiro de. Manual de processo penal: volume único. 5. ed. rev., ampl. e atual. Salvador: JusPodivm, 2017, p. 45.

${ }^{16}$ Em sentido semelhante, quanto a este aspecto específico, cf. GRANDIS, Rodrigo de. Prisões processuais: uma releitura à luz do garantismo penal integral. In: CALABRICH, Bruno; FISCHER, Douglas; PELELLA, Eduardo. Garantismo penal integral: questões penais e processuais, criminalidade moderna e a aplicação do modelo garantista no Brasil. 2 ed. Salvador: Editora JusPodivm, 2013, p. 411-412.

${ }^{17}$ Cf., por todos, LOPES JUNIOR, Aury. Direito processual penal. 14. ed. São Paulo: Saraiva, 2017, p. 647.

${ }^{18}$ STF. HC n ${ }^{\circ}$ 131715/MG. Segunda Turma. Relator Ministro Teori Zavascki. Publicado no DJe em 01/08/2017.

${ }^{19}$ GRECO, Rogério. Curso de Direito Penal: Parte Geral (arts. $1^{\circ}$ a 120 do CP). 15. ed. Rio de Janeiro: Impetus, 2013, p. $475-477$. 
Estabelecida tal diferenciação e, em especial, a limitação à aplicação da prisão-sanção trazida pelo texto constitucional, faz-se imprescindível demonstrar o caráter determinado dos conceitos jurídicos constantes do inciso LVII do art. $5^{\circ}$, do qual decorre a restrita margem de interpretação legada ao operador do direito.

\subsection{DOS CONCEITOS JURÍDICOS DETERMINADOS QUE ENFORMAM A AUTORIZA- ÇÃO CONSTITUCIONAL PARA A PRISÃO-SANÇÃO (ART. $5^{\circ}$, LVII, CF)}

O inciso LVII do art. $5^{\circ}$ da Constituição Federal estatui, in verbis, que "ninguém será considerado culpado até o trânsito em julgado de sentença penal condenatória". A dicção legal não comporta, à primeira vista, maior complexidade. Contudo, as divergências na doutrina e na jurisprudência deixam patente a necessidade de se destrinchar os conceitos que compõem essa norma, de modo a demonstrar que o direito à presunção de inocência recebeu do constituinte delineamento específico, resultando deste o direito fundamental à não execução antecipada da pena.

"Ninguém" e "sentença penal condenatória" não são termos que vêm ensejando debates entre os teóricos e aplicadores do Direito. O mesmo não se dá quanto a "considerado culpado" e "trânsito em julgado".

Em seu voto no $\mathrm{HC} \mathrm{n}^{0} 126.292$, o ministro Gilmar Mendes consignou que "a norma [...] está longe de precisar o que vem a ser considerar alguém culpado", do que resultaria largo espaço de conformação ao legislador, de cuja intermediação dependeria tal definição. Finalizou o ministro aduzindo que o dispositivo constitucional não dá ao réu um direito a ser tratado da mesma forma durante todo o processo.

Ocorre, contudo, que a consideração como culpado corresponde justamente ao juízo de valor que autoriza a execução da pena. Não existe um juízo gradual de culpabilidade que autorizaria uma execução parcial, provisória ou antecipada da pena. Tratar alguém como culpado significa, pois, aplicar uma sanção àquele que se entende responsável, de maneira legalmente inescusável, por uma conduta típica e ilícita.

Aqui importa trazer novamente à baila a diferente autorização constitucional para a prisão cautelar e a prisão-sanção. Quando se emite uma ordem judicial escrita e fundamentada para uma prisão cautelar, por mais que o efeito empírico instantâneo não difira, não se está a considerar o indivíduo culpado, mas tão somen- 
te um risco à coletividade - sendo por isso uma prisão precária, instável. Por outro lado, quando se decreta a prisão para início da execução penal, está se tomando decisão com pretensão de estabilidade, abertamente considerando o indivíduo culpado, o que, nos termos do inciso em comento, só se pode dar após o trânsito em julgado da sentença penal condenatória.

Desse modo, não há como se compreender pela existência de um conceito variável da expressão "considerado culpado". Ela é distinta de "considerado um risco", "considerado possivelmente culpado" ou "considerado provavelmente culpado". "Considerado" é sinônimo de reputado e conduz inexoravelmente à ideia de tratamento; "culpado" é o indivíduo responsável por uma conduta típica, ilícita e juridicamente inescusável. Ausentes do conceito termos imprecisos ou ambíguos, trata-se de conceito jurídico determinado, que restringe a margem de preenchimento pelo aplicador.

O mesmo se verifica em relação ao conceito de "trânsito em julgado". Dispunha o art. 467 do Código de Processo Civil de 1973: "[d]enomina-se coisa julgada material a eficácia que torna imutável e indiscutível a sentença, não mais sujeita a recurso ordinário ou extraordinário". O novo Código de Processo Civil aperfeiçoou o conceito em seu art. 502: "[d]enomina-se coisa julgada material a autoridade que torna imutável e indiscutível a decisão de mérito não mais sujeita a recurso".

Em ambos os casos, a noção de trânsito em julgado converge em seu ponto essencial: a decisão torna-se indiscutível dentro do processo em que foi proferida a partir do momento em que não couber qualquer recurso, independentemente do âmbito de devolução da espécie recursal ${ }^{20}$. O foco está, portanto, na irrecorribilidade.

Parece desarrazoada a posição de que se trataria de construção do direito sempre a serviço do cidadão ${ }^{21}$. Corresponde, com efeito, a uma criação jurídica artificial que objetiva assegurar estabilidade e segurança não só para o cidadão, mas também eventualmente para o Estado, que pretende ver seu interesse - seja um crédito, seja uma punição - realizado pelo direito, além de constituir garantia de efetividade da jurisdição, interesse notório da coletividade.

Parcela da doutrina, com a pretensão de relativizar o conceito, objeta que considerar que o trânsito em julgado da sentença penal condenatória coincide com o momento da irrecorribilidade levaria à não execução de todas as penas. Isso por-

${ }^{20}$ NEVES, Daniel Amorim Assumpção. Manual de direito processual civil. 6. ed., rev., atual. e ampl. Rio de Janeiro: Forense; São Paulo: Método, 2014, p. 609-611.

${ }^{21}$ LOPES JUNIOR, Aury. Direito processual penal. 14. ed. São Paulo: Saraiva, 2017, p. 914. 
que, em sentido técnico-jurídico, nenhuma decisão é absolutamente imutável, pelas hipóteses de revisão criminal e habeas corpus com caráter revisional ${ }^{22}$.

Tal lógica representa evidente reductio ad absurdum, facilmente demonstrável pelo fato de tais hipóteses constituírem ações autônomas, e não recursos na acepção técnica do termo ${ }^{23}$. Como os nomes sugerem, tais ações correspondem a revisão com caráter rescisório, justamente para desconstituição da coisa julgada. E, por imperativo lógico-temporal, só se pode desconstituir a coisa julgada se, em algum momento, operou-se o trânsito em julgado.

Não se pode, por apego a um argumento ou a um desiderato, atribuir a qualquer raciocínio contrário à execução antecipada da pena a pecha de defesa inexorável da impunidade e da inaplicabilidade das sanções penais. O conceito de trânsito em julgado não "continua elástico" ${ }^{4}$, porque nunca o foi, malgrado querelas doutrinárias relativas aos efeitos da coisa julgada, marcadamente na seara processual civil.

É, por certo, conceito jurídico determinado, tanto assim que o Ministério Público Federal, ao deparar-se com recursos manifestamente protelatórios e ilegítimos de determinado réu, vem requerendo ao STF a declaração do trânsito em julgado da condenação ${ }^{25}$. Tal prática, que o STF vem consagrando ${ }^{26}$, revela-se providência absolutamente lícita que, ao não distorcer o conceito de trânsito em julgado, assegura o direito fundamental previsto no inciso LVII do art. $5^{\circ} \mathrm{e}$, ao mesmo tempo, garante a efetividade da função jurisdicional penal.

Fixado o caráter determinado dos conceitos constantes do aludido dispositivo constitucional, cumpre explicitar o conteúdo do direito fundamental ali previsto.

\footnotetext{
${ }^{22}$ Nesse sentido, FRISCHEISEN, Luiza Cristina Fonseca; GARCIA, Mônica Nicida; GUSMAN, Fábio. Execução provisória da pena: um contraponto à decisão do Supremo Tribunal Federal no Habeas Corpus n. 84.078. In: CALABRICH, Bruno; FISCHER, Douglas; PELELLA, Eduardo. Garantismo penal integral: questóes penais e processuais, criminalidade moderna e a aplicação do modelo garantista no Brasil. 2 ed. Salvador: JusPodivm, 2013, p. 455.

${ }^{23}$ LOPES JUNIOR, Aury. Direito processual penal. 14. ed. São Paulo: Saraiva, 2017, p. 1095.

${ }^{24}$ FRISCHEISEN, Luiza Cristina Fonseca; GARCIA, Mônica Nicida; GUSMAN, Fábio. Execução provisória da pena: um contraponto à decisão do Supremo Tribunal Federal no Habeas Corpus n. 84.078. In: CALABRICH, Bruno; FISCHER, Douglas; PELELLA, Eduardo. Garantismo penal integral: questões penais e processuais, criminalidade moderna e a aplicação do modelo garantista no Brasil. 2 ed. Salvador: JusPodivm, 2013, p. 463.

25 STF. AI n 793.454 AgR-ED/SP. Segunda Turma. Relator Ministro Gilmar Mendes. Publicado no DJe em $07 / 02 / 2013$

${ }^{26}$ Cf. a guisa de exemplo, STF. AP n 396 ED-ED/RO. Tribunal Pleno. Relatora Ministra Cármen Lúcia. Publicado no DJe em 30/09/2013.
} 


\subsection{DA EXIGÊNCIA DO TRÂNSITO EM JULGADO DA SENTENÇA CONDENATÓRIA PARA QUE O INDIVÍDUO SEJA PUNIDO}

Não há unanimidade nos campos teórico e prático acerca do conteúdo do princípio da presunção de inocência. Embora signatário da Declaração Universal dos Direitos Humanos da ONU de 1948, que previu tal direito em seu art. 11.1, o Brasil só veio a positivá-lo com a Constituição de 1988, bem como com as tardias ratificações do Pacto Internacional sobre Direitos Civis e Políticos, de 1966 ${ }^{27}$, e da Convenção Americana sobre Direitos Humanos, de 1969 (Pacto de San José da Costa Rica) ${ }^{28}$.

Previsto de maneira genérica nos diplomas internacionais, recebeu atenção pormenorizada na Constituição Federal, por meio de regras e princípios constantes dos incisos do art. $5^{\circ}$.

De acordo com Renato Brasileiro de Lima ${ }^{29}$, no regime constitucional de 1988, decorrem do princípio da presunção de inocência - ou da não culpabilidade - duas regras: a regra probatória (regra de juízo), que atribui à parte acusadora o ônus de demonstrar a culpabilidade do acusado além de qualquer dúvida razoável, e a regra de tratamento, que veda prisóes processuais automáticas ou obrigatórias e impossibilita a execução provisória - ou antecipada - da pena.

Em seu voto no julgamento da medida cautelar das ADCs no 43 e 44, o ministro Dias Toffoli adotou posição convergente com a aludida, apenas separando a regra probatória e a regra do in dubio pro reo. Fundamentou, então, que o art. 283 do CPP densificaria a norma do art. $5^{\circ}$, LVII, ao prever as três formas de prisão: em flagrante, cautelar e sanção.

Assim, como já assentado no item anterior, a Constituição exige o trânsito em julgado para aplicação da sanção, e o art. 283 fez pouco mais que reproduzir os direitos dos acusados já estipulados pela CF/88. Contudo, o Pretório Excelso, em 2016, adotou posição em sentido oposto, insensível inclusive à interpretação intermediária do ministro Dias Toffoli, pela viabilidade da execução provisória da pena com o julgamento do REsp ou do agravo em REsp pelo Superior Tribunal de Justiça.

Note-se que o caráter excepcional do RE e do REsp não é capaz de alterar o conceito de trânsito em julgado, dado que continuam a ser recursos, e não ações

\footnotetext{
${ }^{27}$ Art. 14.2. Pacto ratificado por meio do Decreto ${ }^{\circ} 592$, de 6 de julho de 1992.

${ }^{28}$ Art. 8.2. Convenção ratificada por meio do Decreto n ${ }^{\circ}$ 678, de 6 de novembro de 1992.

${ }^{29}$ LIMA, Renato Brasileiro de. Manual de processo penal: volume único. 5. ed. rev., ampl. e atual. Salvador: JusPodivm, 2017, p. 43-46.
} 
de impugnação com natureza rescisória. O fato de o Código de Processo Civil dispor que tais apelos não dispõem de efeito suspensivo tampouco socorre os defensores da tese, pois não há lacuna ou ambiguidade na legislação penal a autorizar a aplicação supletiva do diploma civil na esfera processual penal ${ }^{30}$.

Ao se pretender executar antecipadamente a pena sob o argumento de que o ora revogado $\S 2^{\circ}$ do art. 27 da lei $n^{\circ} 8.038 / 1990$ atribuía mero efeito devolutivo a tais recursos, da mesma forma que o faz o CPP, em seu art. 637, está-se, ao fim e ao cabo, invertendo a ordem das coisas, isto é, interpretando-se a Constituição com base na lei, e não a lei com base na Constituição.

Compondo a maioria no julgamento do $\mathrm{HC}^{0}{ }^{0} 126.292$, o ministro Luiz Fux argumentou que coisa julgada pode significar a imutabilidade de alguns capítulos da decisão, de modo que seria possível o trânsito em julgado em termos fático-probatórios $^{31}$. Todavia, tal pensamento elastece demasiada e ilogicamente a ideia de capítulos da sentença.

O que o reconhecimento da divisibilidade da sentença enseja é que, em função de a sentença se decompor ideologicamente em partes, haja várias decisões de mérito, nos casos de pedidos decomponíveis ${ }^{32}$. No âmbito processual penal, se o indivíduo for acusado de mais de um crime e houver trânsito em julgado em relação a um deles, evidentemente poderá ser iniciada a execução da pena relativa à condenação transitada. Nessa situação, não se trataria de execução provisória ou antecipada, e sim de cumprimento da sentença condenatória na parte em que se formou a coisa julgada.

Entretanto, não se pode reconhecer que a sentença se divide ideologicamente em capítulos fático-probatórios e capítulos estritamente jurídicos, isto é, a cisão decisória entre fato e direito. Ainda que a construção da sentença se dê separando fatos e fundamentos jurídicos, eles são, para fins de julgamento, incindíveis: não há fato ou fundamento jurídico que baste isoladamente para uma condenação, pois a negação de qualquer deles em relação a um delito importa na negativa da

\footnotetext{
${ }^{30}$ Nesse sentido, cf. LIMA, Renato Brasileiro de. Manual de processo penal: volume único. 5. ed. rev., ampl. e atual. Salvador: JusPodivm, 2017, p. 49-50.

${ }^{31}$ Para uma defesa da necessidade de reconhecimento do "trânsito em julgado dos fatos", cf. FRISCHEISEN, Luiza Cristina Fonseca; GARCIA, Mônica Nicida; GUSMAN, Fábio. Execução provisória da pena: um contraponto à decisão do Supremo Tribunal Federal no Habeas Corpus n. 84.078. In: CALABRICH, Bruno; FISCHER, Douglas; PELELLA, Eduardo. Garantismo penal integral: questões penais e processuais, criminalidade moderna e a aplicação do modelo garantista no Brasil. 2 ed. Salvador: JusPodivm, 2013, p. 465.

32 NEVES, Daniel Amorim Assumpção. Manual de direito processual civil. 6. ed., rev., atual. e ampl. Rio de Janeiro: Forense; São Paulo: Método, 2014, p. 607.
} 
condenação como um todo. Em outras palavras, apenas a conjugação de razões de direito e de fato podem levar a uma condenação definitiva, ou seja, ao trânsito em julgado.

Certo é que, como aduzido pelo ministro Roberto Barroso, em seu voto no $\mathrm{HC} \mathrm{n}^{\circ}$ 126.292, o fundamento para a prisão é ordem escrita e fundamentada do juiz (art. $5^{\circ}, \mathrm{LXI}$ ). Contudo, o fundamento para uma tal ordem vem de outros dispositivos constitucionais e legais.

O status de culpado, por expressa previsão constitucional, reiterada pela legislação infraconstitucional, somente traz consequências com o trânsito em julgado. Antes disso, qualquer prisão deve se dar amparada em um risco que a legislação reconheça e busque combater com uma cautela - casos da prisão para fins de extradição e das prisões temporária e preventiva.

É indiscutível que a CF/88 diferenciou o regime da culpabilidade e o da prisão, como ponderou o ministro Barroso. E justamente por isso se defende que o art. $5^{\circ}$, LVII, por si, limita apenas um tipo de prisão, a prisão-sanção, a qual demanda, como já dito à exaustão, o trânsito em julgado.

No processo civil brasileiro, desde a década de 1990 e com mais força a partir dos anos 2000, mudanças foram introduzidas de modo a se mitigar o valor segurança para prestigiar o valor que a ele se opõe na dogmática contemporânea, a justiça $^{33}$. O mesmo não se deu, contudo, no processo penal, por uma razão muito simples: neste, impera o direito fundamental previsto categoricamente no inciso LVII do art. $5^{\circ}$.

Pelas razões expostas, fica claro que o constituinte foi além da mera previsão de um direito à presunção de inocência e qualificou tal presunção, instituindo o direito fundamental à não execução antecipada da pena.

Visando robustecer a argumentação até aqui exposta, na segunda parte deste artigo, advoga-se a necessidade de se obstar a prisão-sanção a partir da condenação em segunda instância. Isso porque o raciocínio jurídico que a autoriza fá-lo por meio de inaplicável ponderação, possibilitada pela transformação de uma norma-regra em norma-princípio, que acaba por violar o núcleo essencial do direito fundamental atribuído aos indivíduos.

\footnotetext{
33 Sobre a oposição na dogmática contemporânea entre os valores segurança e justiça, cf. SILVA, Ovídio. A. Baptista da. Curso de processo civil: volume 1: processo de conhecimento. 7. ed. rev. e atualizada de acordo com o Código Civil de 2002. Rio de Janeiro: Forense, 2006, p. 458.
} 


\section{DA INCONSTITUCIONALIDADE DA EXECUÇÃO ANTECIPADA DA PENA}

Apesar de sua vocação de permanência, cartas constitucionais não são eternas e não podem ter a pretensão de ser imutáveis ${ }^{34}$. As modificações da Constituição podem se dar por meios tanto formais como informais, sendo o principal exemplo destes últimos as mutações constitucionais, operadas a partir da fixação de novos entendimentos pelas Cortes Supremas ou Constitucionais acerca de determinado dispositivo constitucional.

O histórico do STF relativo ao multicitado inciso LVII do art. $5^{\circ}$ confirma tal ideia, ao mesmo tempo que sugere a ocorrência, a partir de decisões proferidas no 2016, de verdadeira mutação inconstitucional, por violar regra jurídica garantidora do direito fundamental à não execução antecipada da pena.

Nessa senda, a demonstração de que tal norma constitui regra - e não princípio - e de que a execução penal provisória acaba por violar o núcleo essencial desse direito fundamental confere bases sólidas à tese da inconstitucionalidade da execução antecipada, reconhecendo-se, por conseguinte, o acerto da interpretação do STF fixada entre 2009 e 2016, a partir do $\mathrm{HC} \mathrm{n}^{0} 84.078$.

\subsection{DO DIREITO FUNDAMENTAL À NÃO EXECUÇÃO ANTECIPADA DA PENA COMO REGRA JURÍDICA}

Encontra-se superada, em boa medida, na doutrina e na prática constitucional, a ideia de que os princípios, embora constitutivos de diretrizes jurídicas, não têm caráter de norma ${ }^{35}$. Nada obstante, não gera grande divergência a afirmação de que os princípios jurídicos são pautas carecidas de preenchimento para cuja concretização são convocados tanto o legislador como a jurisprudência ${ }^{36}$.

Os trabalhos de Ronald Dworkin, nos Estados Unidos, Robert Alexy, na Alemanha, e Humberto Ávila, no Brasil, representaram, de diferentes formas, avanços doutrinários rumo a uma definição tão precisa quanto possível do que sejam os princípios jurídicos e de sua aplicabilidade. Nesse sentido, esses pensadores ajudaram a superar a noção de que princípios são meras diretivas desprovidas de aplicabilidade

\footnotetext{
34 BARROSO, Luís Roberto. Curso de direito constitucional contemporâneo: os conceitos fundamentais e a construção do novo modelo. 6. ed. São Paulo: Saraiva, 2017, p. 159.

35 Defendendo o caráter de diretriz dos princípios, cf. LARENZ, Karl. Metodologia da ciência do direito. 4. ed. Lisboa: Fundação Calouste Gulbekian, 2005, p. 674-686.

${ }^{36}$ LARENZ, Karl. Metodologia da ciência do direito. 4. ed. Lisboa: Fundação Calouste Gulbekian, 2005, p. 481.
} 
direta, consagrando o entendimento de que constituem verdadeiras normas jurídicas. Embora suas definições de princípio não coincidam, todos partem de sua distinção em relação às regras jurídicas.

Dworkin ${ }^{37}$, o primeiro deles a tratar do tema, diferencia as regras e os princípios a partir da natureza da orientação que oferecem. Assim, as regras são aplicáveis à maneira do "tudo ou nada", isto é, ou a regra é válida, e as respostas que ela prevê devem ser aceitas, ou não é válida e, por conseguinte, não contribui para a decisão a ser tomada.

De seu turno, os princípios não apresentam consequências jurídicas que se seguem automaticamente diante do implemento das condições descritas. Nessa senda, possuem uma dimensão de peso (importância) de que as regras não dispõem, obrigando a uma consideração de sua força relativa em casos de colisão de princípios.

Para $\mathrm{Alexy}^{38}$, os princípios seriam normas que ordenam que algo seja realizado na maior medida possível, consideradas as possibilidades fáticas e jurídicas existentes (mandamentos de otimização), ao passo que as regras seriam sempre ou satisfeitas ou não satisfeitas, contendo, por conseguinte, determinações no âmbito do fática e juridicamente possível.

Em sua Teoria dos Princípios, após analisar vários critérios para a distinção entre regras e princípios ${ }^{39}$, Humberto Ávila define as regras como "normas imediatamente descritivas, primariamente retrospectivas e com pretensão de decidibilidade e abrangência", devendo sua aplicação ser "centrada na finalidade que lhes dá suporte ou nos princípios que lhe são axiologicamente sobrejacentes" ${ }^{40}$; os princípios, por sua vez, são conceituados como "normas imediatamente finalísticas, primariamente prospectivas e com pretensão de complementaridade e de parcialidade", estabelecendo um estado ideal de coisas a ser promovido ${ }^{41}$.

Por qualquer desses conceitos que se adote, pode-se ver que a presunção de inocência, seja como norma implícita, seja como norma prevista nos diversos

\footnotetext{
37 DWORKIN, Ronald. Levando os direitos a sério. 3 edição. São Paulo: WMF Martins Fontes, 2010, p. 39-42.

${ }^{38}$ ALEXY, Robert. Teoria dos direitos fundamentais. Tradução de Virgílio Afonso da Silva da 5 ed. alemã (2006). $2^{\mathrm{a}}$ ediçã̃o. São Paulo: Malheiros, 2017, p. 90-91.

39 ÁVILA, Humberto. Teoria dos princípios: da definição à aplicação dos princípios jurídicos. 17. ed. rev. e atual. São Paulo: Malheiros, 2016, p. 95-102.

${ }^{40}$ ÁVILA, Humberto. Teoria dos princípios: da definição à aplicação dos princípios jurídicos. 17. ed. rev. e atual. São Paulo: Malheiros, 2016, p. 102.

${ }^{41}$ ÁVILA, Humberto. Teoria dos princípios: da definição à aplicação dos princípios jurídicos. 17. ed. rev. e atual. São Paulo: Malheiros, 2016, p. 102 e 107.
} 
documentos internacionais de que o Brasil é signatário, é exemplo de princípio jurídico, enquanto que o inciso LVII do art. $5^{\circ}$ da CF constitui regra jurídica. Houvesse esta norma sido positivada em outros termos, mais vagos, caracterizando um estado ideal de coisas a se alcançar, poderia ser considerada um princípio; na forma como prevista na $\mathrm{CF} / 88$, tê-la por princípio acaba por desfigurá-la em nome da possibilidade de ponderá-la com princípios, algo impossível, já que o constituinte manifestou expressa intenção de densificar a proteção do indivíduo em face do Estado.

Observe-se que o dispositivo constitucional aludido é norma imediatamente descritiva, pois se estabelece uma proibição de tratamento, um comportamento (abstenção) precisamente determinado, com uma pretensão de gerar solução específica para um conflito de razões. Não há generalidade ou vagueza nos conceitos, não há mandamento de otimização, mas um dever-ser que só pode ser realizado à maneira do "tudo ou nada".

Não por outro motivo a doutrina que amparou diversos votos no STF pela execução antecipada ${ }^{42}$ foca na dicção "presunção de inocência" em detrimento da letra da lei - ou, melhor, da letra da Constituição.

Afirma-se, com toda razão, que toda interpretação é "do direito e não de textos isolados" e que "não se interpreta o direito em tiras” ${ }^{\text {”3 }}$. Assim, em sede penal, o direito fundamental à liberdade (art. $5^{\circ}$, caput, CF) e o princípio da presunção de inocência devem ser interpretados e ponderados com o princípio da efetividade da jurisdição penal e o direito fundamental à segurança (art. $6^{\circ}$ e 144, CF).

É essa ponderação que autoriza, por exemplo, o legislador a prever prisões cautelares para casos em que o periculum libertatis ponha em risco bens jurídicos que a Carta Maior igualmente tutela. Não há, pois, confusão alguma em se tratar o inciso LVII do art. $5^{\circ}$ como regra e se reconhecer a possibilidade de prisões cautelares: é a interpretação sistemática desse dispositivo diante do todo constitucional que impede o entendimento pela inconstitucionalidade das prisões cautelares.

Nesse diapasão, interpretar sistematicamente a regra não pode significar transformá-la em princípio simplesmente pelo desejo de vê-la mitigada indiscriminadamente, para todos os casos. É possível que a regra seja afastada ou superada,

${ }^{42}$ Cf. FRISCHEISEN, Luiza Cristina Fonseca; GARCIA, Mônica Nicida; GUSMAN, Fábio. Execução provisória da pena: um contraponto à decisão do Supremo Tribunal Federal no Habeas Corpus n. 84.078. In: CALABRICH, Bruno; FISCHER, Douglas; PELELLA, Eduardo. Garantismo penal integral: questões penais e processuais, criminalidade moderna e a aplicação do modelo garantista no Brasil. 2 ed. Salvador: JusPodivm, 2013, p. 453

43 GRAU, Eros Roberto. Por que tenho medo dos juízes: a interpretação/aplicação do direito e os princípios. 8. ed. refundida do Ensaio e discurso sobre a interpretação/aplicação do direito. São Paulo: Malheiros, 2017, p. 86. 
diante de situações excepcionais em que a realização da justiça no caso concreto pela não aplicação da regra não afete a promoção da justiça para a maior parte dos casos $^{44}$. Não foi, contudo, o que ocorreu nos julgamentos do STF em 2016, em que a transformação artificial de uma regra em princípio propiciou que uma excepcionalidade teórica se tornasse a normalidade fática.

No direito brasileiro, a ponderação que se põe para uma interpretação do direito penal consentânea com a Constituição é entre o direito à liberdade do indivíduo e o direito à segurança dos demais - ambos verdadeiros princípios, que estabelecem estados de coisas a serem buscados ou, na construção de Alexy, mandamentos de otimização. Da mesma forma, é viável uma ponderação entre a presunção de inocência e o direito à segurança, ou entre o direito à liberdade e a efetividade da jurisdição penal, a qual, como já mencionado, conduz à juridicidade das medidas cautelares penais, que se prestam a garantir a utilidade prática do processo.

Constata-se, pois, que a interpretação do STF, fixada em 2009, com o HC $n^{\circ}$ 84.078, e dominante até 2016 não exclui de ponderação o princípio da presunção de inocência e não dilarga excessivamente sua extensão e os direitos dele decorrentes, como se verifica em parte da doutrina de viés garantista ${ }^{45}$. O entendimento então preponderante somente confirmava a evidentemente estreita margem exegética referente ao art. $5^{\circ}$, LVII, da Constituição Federal ${ }^{46}$.

Resta, por derradeiro, expor de que forma a mutação constitucional autorizadora da execução penal provisória acaba por violar o núcleo essencial do direito fundamental consagrado na Constituição.

\subsection{DA VIOLAÇÃO DO NÚCLEO ESSENCIAL DO DIREITO FUNDAMENTAL EM CASO DE EXECUÇÃO PENAL ANTECIPADA}

Ao decidir, no $\mathrm{HC} \mathrm{n}^{0} 126.292$, pela possibilidade de execução provisória da pena, o STF operou verdadeira mutação constitucional, transformando o sentido e o alcance da norma constante do inciso LVII do art. $5^{\circ 47}$. Contudo, ao fazê-lo, a Corte

\footnotetext{
${ }_{44}$ ÁVILA, Humberto. Teoria dos princípios: da definição à aplicação dos princípios jurídicos. 17. ed. rev. e atual. São Paulo: Malheiros, 2016, p. 143.

${ }^{45}$ Cf. LOPES JUNIOR, Aury. Direito processual penal. 14. ed. São Paulo: Saraiva, 2017, p. 95-97.

${ }^{46}$ LIMA, Renato Brasileiro de. Manual de processo penal: volume único. 5. ed. rev., ampl. e atual. Salvador: Ed. JusPodivm, 2017, p. 49.

${ }^{47}$ Para o conceito e os limites de mutação constitucional, cf. BARROSO, Luís Roberto. Curso de direito constitucional contemporâneo: os conceitos fundamentais e a construção do novo modelo. 6. ed. São Paulo: Saraiva, 2017, p. 160 e 164.
} 
Suprema extrapolou os limites reconhecidos para a ocorrência de uma mutação, quais sejam, as possibilidades semânticas do texto normativo e a preservação dos princípios fundamentais que conferem identidade à Constituiçã $0^{48}$.

A forma em que o princípio da presunção de inocência chegou à Constituição Cidadã foi, de fato, extremamente garantista - por certo, não involuntariamente. Ao transformar o sentido literal de conceitos jurídicos determinados, porém, o Poder Judiciário desborda dos sentidos possíveis do texto aludido e, pior, acaba por transformar a identidade da Carta de 1988.

Evidentemente, a Constituição não tem como parte de sua identidade aquele garantismo "hiperbólico monocular" denunciado por parte da doutrina, mas sim o garantismo penal integral, que pretende proteger não só os direitos fundamentais individuais, mas também os coletivos, de titularidade de grupos ou de toda a sociedade $^{49}$. Uma interpretação sistemática da Constituição há que levar em consideração princípios e regras que podem parecer, prima facie, divergentes, de modo a conformá-los uns aos outros, visando, ao fim e ao cabo, à concretização integral da Carta.

Ocorre que a pretendida interpretação sistemática da Constituição operada pelo STF nos julgamentos ocorridos em 2016 acabou por esvaziar completamente o texto do art. $5^{\circ}$, LVII, sob o argumento de necessidade de ponderação do princípio da presunção de inocência. Ao considerar que a aplicação da pena - isto é, o tratamento como culpado - pode se dar antes do trânsito em julgado, nada resta do dispositivo para aplicação e concretização.

Com o alegado pretexto de proteger princípios constitucionais outros, em especial, o da efetividade da jurisdição penal, suprime-se, na prática, um dispositivo constitucional. Isso demonstra o acerto da afirmação posta acima, no sentido de que o inciso LVII é exemplo de regra, e não de princípio: só se pode aplicá-lo na forma "tudo ou nada", como diria Dworkin.

Mesmo que se interpretasse a norma positivada como um princípio jurídico, passível de aplicação por meio de ponderação, o resultado não seria a constitucionalidade da execução penal provisória. Isso porque tal entendimento acabaria por solapar o núcleo essencial do direito fundamental ${ }^{50}$. Como já apontado, ao se

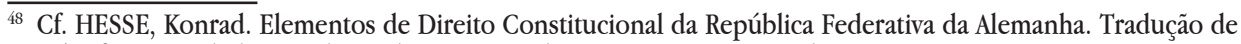
Luís Afonso Heck da 20. edição alemã. Porto Alegre: Sergio Antonio Fabris, 1998, p. 51-52.

${ }^{49}$ FISCHER, Douglas. O que é garantismo penal (integral)? In: CALABRICH, Bruno; FISCHER, Douglas; PELELLA, Eduardo. Garantismo penal integral: questões penais e processuais, criminalidade moderna e a aplicação do modelo garantista no Brasil. 2. ed. Salvador: JusPodivm, 2013, p. 31-32.

${ }^{50}$ Acerca do conteúdo essencial dos direitos fundamentais, cf. ALEXY, Robert. Teoria dos direitos fundamentais. Tradução de Virgílio Afonso da Silva da 5. ed. alemã (2006). 2. ed. São Paulo: Malheiros, 2017, p. 295-300. 
privilegiar o direito à segurança, o direito da vítima a ver seu ofensor punido e o direito a uma jurisdição penal efetiva, em detrimento do direito à não execução antecipada ou provisória da pena, nada sobra deste último.

Dessa forma, esse posicionamento cria uma relação de preferência geral definitiva do princípio da efetividade da jurisdição penal frente ao direito à não execução antecipada da pena. Além dos efeitos práticos deletérios, essa posição vai de encontro à ideia consolidada na doutrina de que o sopesamento tem como resultado um enunciado de preferências condicionadas, dado que constitui uma tarefa de otimização e não um "tudo ou nada" ${ }^{51}$. Resta violado, com isso, também aquilo que Konrad Hesse denomina princípio da concordância prática, consubstanciado na ideia de que bens jurídicos protegidos constitucionalmente devem, na resolução do problema, ser coordenados um ao outro de tal modo que cada um deles ganhe realidade, não podendo um ser realizado à custa do outro ${ }^{52}$.

Toda a discussão aqui versada parece amoldar-se com perfeição ao alerta de Manoel Gonçalves Ferreira Filho:

Em nome dos princípios, por exemplo, há toda uma corrente que pretende ignorar a lei. Com boa intenção, certamente, pretende prevaleçam sempre os princípios sobre as regras. Estes supostos substancialistas esquecem-se de que, assim, renegam o princípio da segurança jurídica, além de contrariarem o próprio princípio democrático ${ }^{53}$.

Os votos dos ministros Teori Zavascki e Gilmar Mendes, no HC n ${ }^{0} 126.292$, trouxeram à baila exemplos de direito comparado, demonstrando a excepcionalidade do caso brasileiro; no mesmo sentido, o voto do ministro Edson Fachin, nas $\mathrm{ADCs} \mathrm{n}^{\circ} 43$ e 44, colocou a questão dos acordos internacionais de que o Brasil é signatário, os quais não protegeriam os acusados na forma consignada a partir do $\mathrm{HC} \mathrm{n}^{\circ}$ 84.078. Entretanto, nem os pactos internacionais podem se sobrepor à letra da Constituição, nem o direito comparado auxilia na resolução do caso, funcionando aqui como mero argumento de autoridade, sequer contribuindo para a interpre-

\footnotetext{
${ }^{51}$ Cf. ALEXY, Robert. Teoria dos direitos fundamentais. Tradução de Virgílio Afonso da Silva da 5. ed. alemã (2006). 2 ed. São Paulo: Malheiros, 2017, p. 173.

${ }^{52}$ HESSE, Konrad. Elementos de Direito Constitucional da República Federativa da Alemanha. Tradução de Luís Afonso Heck da 20 ed. alemã. Porto Alegre: Sergio Antonio Fabris, 1998, p. 66.

${ }^{53}$ FERREIRA FILHO, Manoel Gonçalves. Princípios fundamentais do direito constitucional: o estado da questão no início do século XXI, em face do direito comparado e, particularmente, do direito positivo brasileiro. 4. ed. São Paulo: Saraiva, 2015, p. 209.
} 
tação, dadas as profundas diferenças entre os enunciados normativos e os sistemas penais e processuais penais dos países contrastados.

Desnecessário lembrar que em nenhum documento o Brasil se obriga a executar antecipadamente a pena, mas tão somente a empreender esforços para punir devidamente determinados crimes, atentar para o interesse das vítimas em ver o autor do crime punido e otimizar a aplicação da lei penal. Todos esses objetivos podem ser buscados de diversos modos que não a execução antecipada da pena, como é o caso da baixa imediata para execução - com reconhecimento do trânsito em julgado - nos casos em que evidenciado o caráter meramente protelatório do recurso do acusado ${ }^{54}$.

Ainda, descabe mitigar a gravidade da supressão do direito fundamental sob o fundamento de que sempre haverá a possibilidade de concessão excepcional de efeito suspensivo aos recursos extraordinário e especial55. Na seara penal, o que é excepcional e só pode ser aplicada, quando muito, em casos concretos dotados de circunstâncias ímpares, é a execução antecipada da pena.

Não podem ser ignorados os elementos e argumentos de ordem pragmática trazidos à discussão por diversos ministros do STF nos últimos anos: a ineficiência da jurisdição penal, o excesso de recursos protelatórios, a sensação de impunidade, a seletividade do sistema penal. Porém, não se pode pretender que uma norma prevista como proteção individual contra o Estado e eventuais maiorias seja completamente suprimida sob alegação de não encontrar ressonância no meio social.

\section{CONCLUSÃO}

O presente artigo teve por desiderato demonstrar que a execução antecipada da pena, objeto de oscilação histórica na jurisprudência do Supremo Tribunal Federal, configura verdadeira mutação constitucional, mas, paradoxalmente, uma mutação inconstitucional, por violar direito fundamental previsto no art. $5^{\circ}$, LVII, da Constituição Federal.

Tal conclusão partiu da diferenciação de fundamentos e de aplicação dos regimes de prisão cautelar e de prisão-sanção, apta a demonstrar a total viabilidade do

\footnotetext{
${ }^{54}$ Nesse sentido, cf. LIMA, Renato Brasileiro de. Manual de processo penal: volume único. 5. ed. rev., ampl. e atual. Salvador: Ed. JusPodivm, 2017, p. 49-50.

55 Cf. FISCHER, Douglas. O que é garantismo penal (integral)? In: CALABRICH, Bruno; FISCHER, Douglas; PELELLA, Eduardo. Garantismo penal integral: questões penais e processuais, criminalidade moderna e a aplicação do modelo garantista no Brasil. 2. ed. Salvador: JusPodivm, 2013, p. 51.
} 
reconhecimento da prisão cautelar sem que se aceite a execução penal provisória. Contribuiu também a exposição da clareza do dispositivo constitucional, formado por conceitos jurídicos determinados que deixam diminuta margem para interpretação do operador do direito.

Nesse sentido, procurou-se apresentar fundamentada divergência em face dos argumentos trazidos pela doutrina especializada e por ministros do STF que entendem viável a execução antecipada. Arguiu-se, assim, pela caracterização do direito fundamental à não execução antecipada da pena como regra jurídica, e não como princípio, sendo inaplicável, portanto, com base em técnica de ponderação.

Conclui-se, pois, pela inconstitucionalidade de decisões que autorizem a execução penal antecipada, em razão de constituir violação ao núcleo essencial de um direito fundamental consagrado na Constituição de 1988.

Em arrimo a essa conclusão, cabe lembrar o ensinamento de Konrad Hesse de que "[t]odos os interesses momentâneos - ainda quando realizados - não logram compensar o incalculável ganho resultante do comprovado respeito à Constituição, sobretudo naquelas situações em que a sua observância revela-se incômoda" ${ }^{" 56}$. Sempre é tempo para se provar o acerto de Hamilton ao afirmar que, embora a opressão individual possa eventualmente provir dos Tribunais, a liberdade geral do povo jamais será posta em perigo pelo Poder Judiciário ${ }^{57}$.

\section{REFERÊNCIAS}

ALEXY, Robert. Teoria dos direitos fundamentais. Tradução de Virgílio Afonso da Silva da 5. ed. alemã (2006). 2. ed. São Paulo: Malheiros, 2017.

ÁVILA, Humberto. Teoria dos princípios: da definição à aplicação dos princípios jurídicos. 17. ed. rev. e atual. São Paulo: Malheiros, 2016.

BARROSO, Luís Roberto. Curso de direito constitucional contemporâneo: os conceitos fundamentais e a construção do novo modelo. 6. ed. São Paulo: Saraiva, 2017.

BRASIL. Constituição de República Federativa do Brasil de 1988. Disponível

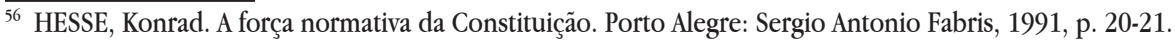

${ }^{57}$ HAMILTON, Alexander; JAY, John; MADISON, James. The federalist papers. [S.l.] Black \& White Publications, 2015, p. 241. No original: "[...] though individual oppression may now and then proceed from the courts of justice, the general liberty of the people can never be endangered from that quarter". 
em http://www.planalto.gov.br/ccivil_03/constituicao/ConstituicaoCompilado.htm. Acesso em: 29 jan. 2018.

BRASIL. Decreto-lei $\mathbf{n}^{0}$ 3.689, de 3 de outubro de 1941. Disponível em: http:// www.planalto.gov.br/ccivil_03/decreto-lei/Del3689Compilado.htm. Acesso em: 29 jan. 2018.

BRASIL. Supremo Tribunal Federal. Ação Declaratória de Constitucionalidade. ADC $n^{0}$ 43. Tribunal Pleno. Requerente: Conselho Federal da Ordem dos Advogados do Brasil. Relator Min. Marco Aurélio. Brasília, 5 de outubro de 2016. Disponível em: http://portal.stf.jus.br/processos/detalhe.asp?incidente $=4986065$. Acesso em: 29 jan. 2018. (Acórdão não publicado.)

BRASIL. Supremo Tribunal Federal. Agravo em Recurso Extraordinário. ARE $\mathbf{n}^{\mathbf{o}}$ 964.246. Tribunal Pleno. Recorrente: M.R.D. Recorrido: Ministério Público do Estado de São Paulo. Relator Min. Teori Zavascki. Brasília, 10 de novembro de 2016. Disponível em: http://portal.stf.jus.br/processos/detalhe.asp?incidente $=4966379$. Acesso em: 29 jan. 2018.

BRASIL. Supremo Tribunal Federal. Embargos de Declaração em Agravo Regimental em Agravo de Instrumento. AI $\mathbf{n}^{\mathbf{0}} \mathbf{7 9 3 . 4 5 4}$ AgR-ED. Segunda Turma. Embargante: Paulo Theotonio Costa. Embargado: Ministério Público Federal. Relator Min. Gilmar Mendes. Brasília, 4 de dezembro de 2012. Disponível em: http://portal.stf.jus.br/processos/detalhe.asp?incidente $=3858428$. Acesso em: 29 jan. 2018 .

BRASIL. Supremo Tribunal Federal. Embargos de Declaração em Embargos de Declaração em Ação Penal. AP no 396 ED-ED. Tribunal Pleno. Embargante: Natan Donadon. Embargado: Ministério Público do Estado de Rondônia. Relator Min. Cármen Lúcia. Brasília, 26 de junho de 2013. Disponível em: http://portal.stf.jus.br/processos/detalhe.asp?incidente =2316196. Acesso em: 29 jan. 2018.

BRASIL. Supremo Tribunal Federal. Habeas Corpus. $\mathbf{H C} \mathbf{n}^{\mathbf{0}}$ 68.726. Tribunal Pleno. Impetrante: Fernando Eduardo Ayres da Motta. Coator: Tribunal de Alçada Criminal do Estado do Rio de Janeiro. Paciente: Marco Antonio da Fonseca Loureiro. Relator Min. Néri da Silveira. Brasília, 28 de junho de 1991. Disponível em: http://portal. stf.jus.br/processos/detalhe.asp?incidente =1521108. Acesso em: 29 jan. 2018.

BRASIL. Supremo Tribunal Federal. Habeas Corpus. HC $\mathbf{n}^{\mathbf{0}}$ 84.078. Tribunal Pleno. 
Impetrante e paciente: Omar Coelho Vitor. Coator: Superior Tribunal de Justiça. Relator Min. Eros Grau. Brasília, 5 de fevereiro de 2009. Disponível em: http://portal. stf.jus.br/processos/detalhe.asp?incidente $=2208796$. Acesso em: 29 jan. 2018.

BRASIL. Supremo Tribunal Federal. Habeas Corpus. HC $\mathbf{n}^{\mathbf{0}}$ 126.292. Tribunal Pleno. Impetrante: Maria Claudia de Seixas. Paciente: Marcio Rodrigues Dantas. Coator: Relator do $\mathrm{HC}^{0} 313.021$ do Superior Tribunal de Justiça. Relator Min. Teori Zavascki. Brasília, 17 de fevereiro de 2016. Disponível em: http://portal.stf.jus.br/processos/detalhe.asp?incidente $=4697570$. Acesso em: 29 jan. 2018 .

BRASIL. Supremo Tribunal Federal. Habeas Corpus. HC no 131.715. Segunda Turma. Impetrante: Fabio Vieira da Silveira e outro. Paciente: Nilson Ferreira da Cruz. Coator: Relator do RHC n ${ }^{0} 53.071$ do Superior Tribunal de Justiça. Relator Min. Teori Zavascki. Brasília, 6 de setembro de 2016. Disponível em: http://portal.stf.jus.br/processos $/$ detalhe.asp?incidente $=4891850$. Acesso em: 29 jan. 2018.

DWORKIN, Ronald. Levando os direitos a sério. 3. ed. São Paulo: WMF Martins Fontes, 2010.

FERREIRA FILHO, Manoel Gonçalves. Princípios fundamentais do direito constitucional: o estado da questão no início do século XXI, em face do direito comparado e, particularmente, do direito positivo brasileiro. 4. ed. São Paulo: Saraiva, 2015.

FISCHER, Douglas. O que é garantismo penal (integral)? In: CALABRICH, Bruno; FISCHER, Douglas; PELELLA, Eduardo. Garantismo penal integral: questões penais e processuais, criminalidade moderna e a aplicação do modelo garantista no Brasil. 2. ed. Salvador: JusPodivm, 2013.

FRISCHEISEN, Luiza Cristina Fonseca; GARCIA, Mônica Nicida; GUSMAN, Fábio. Execução provisória da pena: um contraponto à decisão do Supremo Tribunal Federal no Habeas Corpus n. 84.078. In: CALABRICH, Bruno; FISCHER, Douglas; PELELLA, Eduardo. Garantismo penal integral: questões penais e processuais, criminalidade moderna e a aplicação do modelo garantista no Brasil. 2. ed. Salvador: JusPodivm, 2013.

GRECO, Rogério. Curso de Direito Penal: Parte Geral (arts. $1^{\circ}$ a 120 do CP). 15. ed. Rio de Janeiro: Impetus, 2013. 
GRANDIS, Rodrigo de. Prisões processuais: uma releitura à luz do garantismo penal integral. In: CALABRICH, Bruno; FISCHER, Douglas; PELELLA, Eduardo. Garantismo penal integral: questões penais e processuais, criminalidade moderna e a aplicação do modelo garantista no Brasil. 2. ed. Salvador: JusPodivm, 2013.

GRAU, Eros Roberto. Por que tenho medo dos juízes: a interpretação/aplicação do direito e os princípios. 8. ed. refundida do Ensaio e discurso sobre a interpretação/ aplicação do direito. São Paulo: Malheiros, 2017.

HAMILTON, Alexander; JAY, John; MADISON, James. The federalist papers. [S.I.] Black \& White Publications, 2015.

HESSE, Konrad. A força normativa da Constituição. Porto Alegre: Sergio Antonio Fabris, 1991.

HESSE, Konrad. Elementos de Direito Constitucional da República Federativa da Alemanha. Tradução de Luís Afonso Heck da 20. ed. alemã. Porto Alegre: Sergio Antonio Fabris, 1998.

LARENZ, Karl. Metodologia da ciência do direito. 4 ed. Lisboa: Fundação Calouste Gulbekian, 2005

LIMA, Renato Brasileiro de. Manual de processo penal: volume único. 5. ed. rev., ampl. e atual. Salvador: JusPodivm, 2017.

LOPES JUNIOR, Aury. Direito processual penal. 14. ed. São Paulo: Saraiva, 2017.

NEVES, Daniel Amorim Assumpção. Manual de direito processual civil. 6. ed., rev., atual. e ampl. Rio de Janeiro: Forense; São Paulo: Método, 2014.

SILVA, Ovídio. A. Baptista da. Curso de processo civil: volume 1: processo de conhecimento. 7. ed. rev. e atualizada de acordo com o Código Civil de 2002. Rio de Janeiro: Forense, 2006. 
